\title{
Prevalence and antimicrobial resistance of Salmonella spp. isolated from free-ranging wild boars in the State of São Paulo, Brazil
}

\section{Paulo Eduardo Carraro ${ }^{*}$ (D) Fernanda de Oliveira Barbosa ${ }^{1}$ (D) Valdinete Pereira Benevides $^{1}(\mathbb{D}$

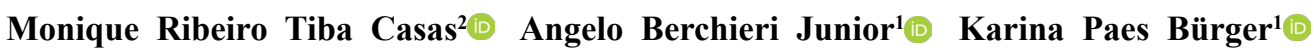

${ }^{1}$ Departamento de Patologia, Reprodução e Saúde Única, Faculdade de Ciências Agrárias e Veterinárias (FCAV) Universidade Estadual Paulista (UNESP), 14884-900, Jaboticabal, SP, Brasil. E-mail: ducarrarovet@hotmail.com. "Corresponding author.

${ }^{2}$ Instituto Adolfo Lutz, Núcleo de Doenças e Infecções Entéricas por Patógenos Especiais, Centro de Bacteriologia, São Paulo, SP, Brasil.

ABSTRACT: European wild boars (Sus scrofa) are considered exotic invasive species worldwide. Invasions of wild boars are a growing public health concern, as wild boars may represent an important reservoir of zoonotic pathogens, including bacteria of the genus Salmonella. The aim of this study was to determine the prevalence and serovars of Salmonella spp. in free-ranging wild boars legally hunted in the state of São Paulo, Brazil, and the susceptibility of those Salmonella spp. to antimicrobials. Fecal samples and mesenteric lymph nodes were acquired from 63 wild boars. The prevalence of Salmonella spp. in free-ranging wild boars was 9.5\% (6/63; confidence interval: $4.4 \%$ - 19.2 $\%$ ). Six serovars were isolated: S. enterica subsp. enterica ser. 4,5,12:-:1,2, S. enterica ser. Cerro, S. enterica ser. Madelia, S. enterica ser. Typhimurium, S. enterica ser. I (4,5,12:i:-) and S. enterica ser. Muenster. Analysis of antimicrobial resistance of Salmonella spp. showed that the majority of serovars were fully susceptible to the tested antimicrobials. Only S. enterica ser. Typhimurium and S. enterica ser. Muenster showed a resistance pattern to at least one antimicrobial analyzed. To our knowledge, this study is the first report the prevalence and serovars of Salmonella spp. in free-ranging wild boars in the State of São Paulo, Brazil. Results indicate a low prevalence with variability of Salmonella serovars, with some pattern of antimicrobial resistance. This study highlights the potential role of wild boars as carriers of Salmonella and could pose a risk to wild and domestic animals as well as humans.

Key words: salmonellosis, public health, Sus scrofa, wildlife, reservoir.

Prevalência e resistência antimicrobiana de Salmonella spp. isoladas em javalis de vida livre no Estado de São Paulo

RESUMO: Os javalis europeus (Sus scrofa) são considerados uma espécie exótica invasora em todo o mundo. As invasões de javalis são uma preocupação crescente de saúde pública, pois os javalis podem representar um importante reservatório de patógenos zoonóticos, incluindo bactérias do gênero Salmonella. O objetivo deste estudo foi determinar a prevalência e os sorovares de Salmonella spp. em javalis de vida livre caçados legalmente no Estado de São Paulo, Brasil, e a suscetibilidade dessa Salmonella spp. aos antimicrobianos. Amostras fecais e linfonodos mesentéricos foram adquiridos de 63 javalis. A prevalencia de Salmonella spp. em javalis selvagens foi de 9,5\% (6/63; intervalo de confiança: 4,4\% - 19,2\%). Seis sorovares foram isolados: S. enterica subsp. enterica ser. 4,5,12:-: 1,2, S. enterica ser. Cerro, S. enterica ser. Madelia, S. enterica ser. Typhimurium, S. enterica ser. I (4,5,12:i:-) e S. enterica ser. Muenster. As análises de resistência antimicrobiana de Salmonella spp. evidenciaram que a maioria dos sorovares era pansensivel aos antimicrobianos testados. Apenas $S$. enterica ser. Typhimurium e S. enterica ser. Muenster mostraram um padrão de resistência a pelo menos um antimicrobiano analisado. A saber, este estudo é o primeiro relato da prevalência e de sorovares de Salmonella spp. em javalis de vida livre no Estado de São Paulo, Brasil. Os resultados indicaram baixa prevalência com variabilidade de sorovares de Salmonella, com algum padrão de resistência antimicrobiana. Este estudo destaca o papel potencial dos javalis como portadores de Salmonella spp. e pode representar um risco para os animais domésticos e selvagens, bem como para os humanos.

Palavras-chave: salmonelose, saúde pública, Sus scrofa, selvagem, reservatório.

\section{INTRODUCTION}

European wild boars (Sus scrofa) are considered exotic invasive species in several countries, including Brazil (BARRIOS-GARCIA \& BALLARI, 2012; PEDROSA et al., 2015). An increase in wild boar populations has been observed worldwide (FREDRIKSSON-AHOMAA, 2019). In Brazil, studies on distribution of wild boars in 2015, has shown their occupation of more than 472 Brazilian municipalities. São Paulo was the most affected state, with Sus scrofa present in $24.18 \%(156 / 645)$ of its 
municipalities, followed by the states of Rio Grande do Sul (11.08 \%; 55/496) and Minas Gerais (10.66\%; 91/853) (PEDROSA et al., 2015).

Because of the growth in the wild boar populations and their negative impacts on native flora and fauna, agriculture and public health, the hunting of wild boars has been allowed since 2013 by the Brazilian Institute of Environment and Renewable Natural Resources (IBAMA) as a method of population control in Brazil (BRASIL, 2013).

In the last decade, concern over the public health implications of wild boars has grown, as they may represent an important reservoir of zoonotic pathogens, including bacteria of the genus Salmonella (WACHECK et al., 2010). Moreover, antimicrobial resistance occurs frequently in the environment, directly affecting populations of domestic and wild animals (LITERAK et al., 2010), and, consequently, can reduce therapeutic options for bacterial infections in humans (EIBACH et al., 2016). This problem can be aggravated by occasional migrations of wild boars close to domestic herds and human habitats because this greatly increases the possibility of pathogens being naturally transmitted between the wild boars and either domestic animals or humans (MEIER \& RYSER-DEGIORGIS, 2018).

A disease that is prevalent in wild boar populations would be extremely difficult to control and eradicate and could cause health damages to livestock and economic embargos on the exportation of animal products (PIRES et al., 2013). Hence, the epidemiological surveillance of Salmonella spp. in wild boars contributes to the epidemiological understanding of the pathogen and the occurrence of its resistance to antimicrobials (FISCHER et al., 2014; QUESADA et al., 2015).

Considering inadequate data on the prevalance and resistance pattern of Salmonella spp. in wild boar populations throughout Brazil, further studies are needed to provide more data. The aim of this study was to determine the prevalence and serovars of Salmonella spp., as well as their susceptibility profiles to antimicrobials in free-ranging wild boars hunted in the State of São Paulo, Brazil.

\section{MATERIALS AND METHODS}

\section{Sample collection}

Convenience samples were collected between January 2018 and February 2019. Fecal samples and mesenteric lymph nodes were collected from wild boar legally hunted on farms located in the State of São Paulo. The study area was composed of the following municipalities: Barretos, Guaraci, Olímpia, Colina, Jaboticabal and Torrinha (Figure 1). The study region was characterized by the cultivation

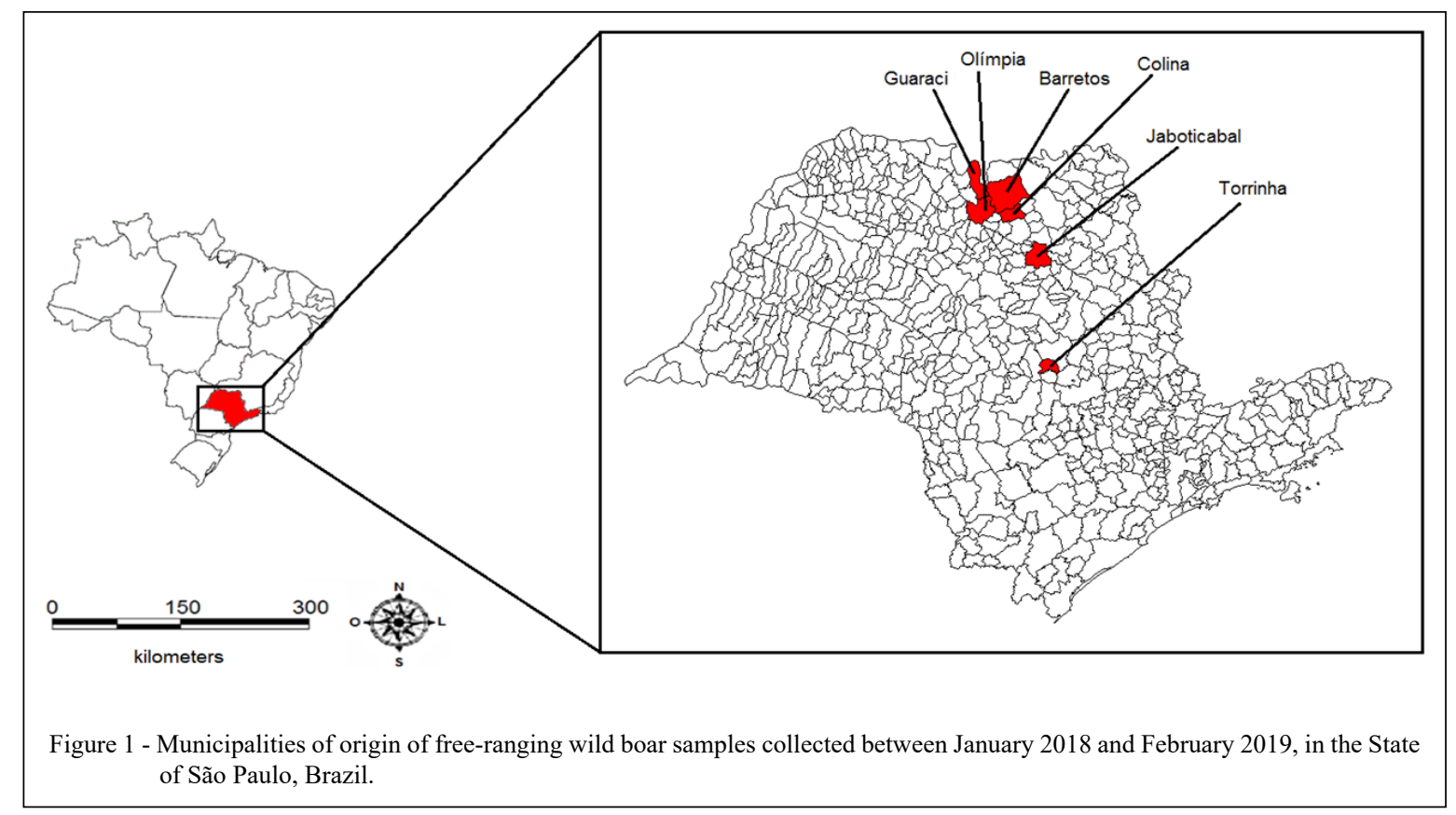

Ciência Rural, v.52, n.8, 2022. 
of sugarcane and orange. Additional features of the study area included running watercourses, pastures, native forests with swamp formations, and the presence of domestic animals, mainly cattle and dogs.

The feces were collected using rectal swabs and placed in falcon tubes containing $10 \mathrm{ml}$ of $1 \%$ peptone water. After each hunt, each wild boar carcass was subject to standard necropsy, and the mesenteric lymph nodes were collected through incision by which approximately $5 \mathrm{~g}$ of tissue was obtained and placed in a sterile vial. Both samples were refrigerated until laboratory tests were performed, at a temperature between $2{ }^{\circ} \mathrm{C}$ and $8{ }^{\circ} \mathrm{C}$, for up to $24 \mathrm{~h}$.

\section{Isolation and identification of Salmonella spp.}

Isolation and identification of the Salmonella genus (microbiological and molecular assays) were performed at the Ornithopathology Laboratory of the Faculty of Agricultural and Veterinary Sciences of FCAV/Unesp. Presumed Salmonella colonies were subjected to polymerase chain reaction (PCR) targeting the invA gene to confirm the genus, as described by FRATAMICO \& STROBAUGH (1998). Positive samples in both microbiological and molecular assays were submitted to the Enterobacteria Section of Adolfo Lutz Institute, São Paulo, SP, Brazil, for serovar identification (BRASIL, 1995).

\section{Assessment of susceptibility to antimicrobials}

The antimicrobial sensitivity of Salmonella strains was evaluated by Kirby-Bauer disk diffusion and minimal inhibitory concentration(MIC) tests. Escherichia coli strain ATCC ${ }^{\circledR} 25922^{\mathrm{TM}}$ was used for quality control. Twenty antimicrobials from nine different classes were used: nalidixic acid $30 \mu \mathrm{g} / \mathrm{mL}$, enrofloxacin $5 \mu \mathrm{g} / \mathrm{mL}$, ciprofloxacin $5 \mu \mathrm{g} / \mathrm{mL}$, chloramphenicol $30 \mu \mathrm{g} / \mathrm{mL}$, aztreonam $30 \mu \mathrm{g} / \mathrm{mL}$, streptomycin $10 \mu \mathrm{g} / \mathrm{mL}$, gentamicin $10 \mu \mathrm{g} / \mathrm{mL}$, sulfonamide $300 \mu \mathrm{g} / \mathrm{mL}$, trimethoprim 1.25 $\mu \mathrm{g} / \mathrm{mL}$, sulfamethoxazole $23.75 \mu \mathrm{g} / \mathrm{mL}$, imipenem 10 $\mu \mathrm{g} / \mathrm{mL}$, cefoxitin $30 \mu \mathrm{g} / \mathrm{mL}$, cefotaxime $30 \mu \mathrm{g} / \mathrm{mL}$, cefepime $30 \mu \mathrm{g} / \mathrm{mL}$, ceftiofur $30 \mu \mathrm{g} / \mathrm{mL}$, ampicillin 10 $\mu \mathrm{g} / \mathrm{mL}$, amoxicillin $10 \mu \mathrm{g} / \mathrm{mL}$, amoxicillin and clavulanic Acid 10 and $20 \mu \mathrm{g} / \mathrm{mL}$, respectively; tetracycline $30 \mu \mathrm{g} /$ $\mathrm{mL}$, phosphomycin $200 \mu \mathrm{g} / \mathrm{mL}$ and polymyxin E 0.125 $32 \mu \mathrm{g} / \mathrm{mL}$.

The MIC test was performed only for polymyxin E, and strain resistance was assumed when antimicrobial concentration was higher than 2 $\mu \mathrm{g} / \mathrm{mL}$. The results were compared with the standards of the Clinical and Laboratory Standards Institute guidelines (CLSI, 2017). Intermediate profiles were assumed to be resistant to the disk diffusion test
(FIROOZEH et al., 2011). Serovars resistant to three or more antimicrobials from different classes were considered multiresistant (SCHWARZ et al., 2010).

\section{Statistical analysis}

Descriptive statistics of the variables studied were performed with frequency distribution and calculation of the $95 \%$ confidence interval (CI) of prevalence rates.

\section{RESULTS}

Fecal samples $(n=63)$ and mesenteric lymph nodes samples $(n=11)$ were collected from 63 wild boars legally hunted in the State of São Paulo. From the wild boars, 46 were from Barretos, eight from Guaraci, four from Olímpia, three from Colina and one each from Torrinha and Jaboticabal.

In the present study, the prevalence of Salmonella spp. in free-ranging wild boars in the State of São Paulo was 9.5 \% (6/63; CI: $4.4 \%-19.2 \%)$, with six different serovars isolated (Table 1). Four serovars were recovered in feces $(6.35 \%$; 4/63; CI: $2.49 \%$ - $15.22 \%$ ), and three serovars from lymph nodes (27.27\%; 3/11; CI: $9.74 \%-56.56 \%$ ). Two serovars were isolated from the wild boar 4: S. enterica ser. Typhimurium and S. enterica ser. Cerro. In Barretos, five samples were positive (83.3\%; 5/6; CI: $44 \%$ - 97 $\%$ ), and only one was positive for Torrinha, (6.6\%; 1/6; CI: $2.99 \%-56.3 \%$ ). All suggestive Salmonella isolates were positive by PCR targeting inv $A$ gene.

Analysis of antimicrobial resistance of Salmonella spp. isolated from wild boars showed that the majority of serovars were full susceptible to the tested antimicrobials $(66.6 \%$; $4 / 6$; CI: $30.0 \%$ $-90.3 \%)$. Only two strains $(33.3 \%$; $2 / 6$; CI: $47.8 \%$ - 108.2\%), belonging to serovars $S$. enterica ser. Typhimurium and $S$. enterica ser. Muenster, showed a resistance pattern to at least one antimicrobial analyzed. The serovar $S$. enterica ser. Typhimurium showed resistance to enrofloxacin, tetracycline and ampicillin, and was classified as a multiresistant strain (resistant to three or more antimicrobials of different classes). While $S$. enterica ser. Muenster was resistant to ciprofloxacin and nalidixic acid. The isolates tested in the MIC analysis for polymyxin E did not show resistance.

\section{DISCUSSION}

The results obtained in this study confirmed the presence of Salmonella spp. in wild boars (9.5 $\%-6 / 63$ ) in some regions of the State of São Paulo, 
Table 1 - Salmonella prevalence and serovars identified in wild boars (Sus scrofa) in the North, Northeast and Midwest regions of the State of São Paulo.

\begin{tabular}{|c|c|c|c|c|}
\hline Municipality & Prevalence $(\mathrm{n} / \mathrm{N})^{1} \mathrm{CI} 95^{2}$ & Animal $\mathrm{ID}^{3}$ & Isolated serotypes & Origin of samples \\
\hline Torrinha & $6.6 \%(1 / 6)(2.9 \%-56.3 \%)$ & Wild boar 1 & S. enterica subsp. enterica ser. $4,5,12:-: 1,2$ & Feces \\
\hline \multirow{6}{*}{ Barretos } & \multirow{6}{*}{$83.3 \%(5 / 6)(44 \%-97 \%)$} & Wild boar 2 & S. enterica ser. Cerro & Feces \\
\hline & & Wild boar 3 & S. enterica ser. Madelia & Feces \\
\hline & & \multirow{2}{*}{ Wild boar 4} & S. enterica ser. Typhimurium & Feces \\
\hline & & & S. enterica ser. Cerro & Lymph node \\
\hline & & Wild boar 5 & S. enterica ser. I $(4,5,12: \mathrm{i}:-)$ & Lymph node \\
\hline & & Wild boar 6 & S. enterica ser. Muenster & Lymph node \\
\hline
\end{tabular}

1- positive wild boars/total of wild boars tested; 2 - $95 \%$ confidence interval; 3 - wild boar identification.

Brazil. Even though a low prevalence of Salmonella spp. was observed among the wild boars sampled in this study, results indicate that free-ranging wild boars can still be a source of Salmonella spp. infections for livestock and humans, and highlight the potential role wild boars can play as carriers of this zoonotic agent (CARLSON et al., 2011; HILBERT et al., 2012).

Wild boar carcass contaminated with Salmonella spp. could transmit the pathogen to humans through consumption of raw or undercooked meat (SANNÖ et al., 2018). The risk of Salmonella being transmitted to humans from wild boar carcasses is corroborated by inadequate hygiene practices in the handling and preparation of wild boar carcasses, such as evisceration in the soil and washing of the carcass after evisceration, which contribute to the higher frequency of carcass contamination (MIRCETA et al., 2017).

Among the isolates, our results confirm the presence of Salmonella enterica serovars that are of importance to public health, such as $S$. enterica subsp. enterica ser. 4,5,12:-:1,2 and $S$. enterica ser. I (4,5,12:i:-). Both are atypical and emergent monophasic serovars, that share almost all antigen with $S$. enterica ser. Typhimurium (ECHEITA et al., 2001), a serovar also isolated in this study.

Salmonella enterica ser. Typhimurium and monophasic $S$. enterica ser. Typhimurium $(1,4,[5], 12: \mathrm{i}:-)$ are the two most commonly reported Salmonella serovars in human outbreaks (EFSA, 2017). In Brazil, between the years of 2000 and 2018, Salmonella spp. was the pathogen most frequently associated with outbreaks (FINGER et al., 2019).

The prevalence of Salmonella spp. in wild boars observed in this study matches the prevalence observed in other regions. THAKUR et al. (2011) reported $5 \%(8 / 161)$ prevalence in wild boars in the USA, while MOLINA-LÓPEZ (2015) and MOLINO et al. (2019) reported a prevalence of $4.2 \%(11 / 263)$ and $7.7 \%(81 / 1041)$, respectively, in Spain. Currently, the only other study in Brazil is for the State of Goias which found $1 \%(1 / 100)$ prevalence of Salmonella spp. in samples of wild boar feces collected from commercial farms (FARIA, 2016). However, studies outside of Brazil have measured higher prevalence of Salmonella in wild boars. For instance, VIEIRAPINTO (2011) measured a prevalence of $22.1 \%$ (17/77) in Portugal, and CHIARI (2013) measured a prevalence of $24.8 \%(326 / 1313)$ in Italy.

The presence of cattle on pasture possibly contributed to the occurrence of Salmonella spp. in this study, because cattle shared the same habitat as wild boars. In Spain, NAVARRO-GONZALEZ et al. (2012) concluded that wild boars from cattle-free areas had a lower Salmonella spp. prevalence than of those that co-habited with cattle.

Salmonella spp. in wildlife has often been associated with serovar $S$. enterica ser. Typhimurium, but a greater diversity of serovars have been isolated in recent years (PAULSEN et al., 2012; MOLINO et al., 2019). The isolation of other serovars in this study, such as S. enterica ser. Muenster, S. enterica ser. Cerro and $S$. enterica ser. Madelia, reflects the high variability of Salmonella serovars found in wildlife. The S. enterica ser. Madelia is usually found in the fish production chain, for instance, in schrimp (BESHIRU et al., 2019). While $S$. enterica ser. Cerro and S. enterica ser. Muenster have been described in cattle and poultry (KOVAC et al., 2017; NOUICHI et al., 2018; LÚCIO et al., 2019; JIBRIL et al., 2021).

Variability in the presence of different Salmonella serovars and the prevalence of Salmonella 
is attributed to different sources of exposure such as: waste disposal (BALL et al., 2020), livestock, and other wild species such as birds and reptiles (PAULSEN et al., 2012). Variability is further the result of through direct contact, the sharing of resources used by food animals (specially pastured livestock), water cross-contamination and omnivore feeding habits such as the consumption of small animals carrying Salmonella spp. or contaminated carcasses (AVAGNINA et al., 2012; NAVARROGONZALEZ et al., 2012).

In wild fauna, investigations of antimicrobial resistance are highly variable in their results and depend mainly on the host species, etiologic agent and geographic location. Humans may be the main source of antimicrobial resistance found in wild life, owing to the indiscriminate use of antimicrobials (NAVARRO-GONZALEZ et al., 2012; EIBACH et al., 2016).

Similar to the present study, resistance to ciprofloxacin and nalidixic acid was observed in $S$. enterica ser. Enteritidis isolated from the feces of wild boar present in northeastern Spain (NAVARROGONZALEZ et al., 2012). FARIA (2016) reported Salmonella spp. resistant to tetracycline and ampicillin, as well as to the chloramphenicol, neomycin, amoxicillin and sulfonamide in wild boar fecal samples from a commercial breeding system in Brazil. Animals submitted to industrialized production systems carry bacteria with greater levels of virulence and resistance factors, because of the greater pressure of natural selection, as was corroborated by SCHIERACK et al. (2013).

Furthermore, the resistance pattern of Salmonella spp. to antimicrobials in different samples of farm animals has also been reported, as several studies have shown that Salmonella spp. have antimicrobial resistance, especially to the nalidixic acid, ciprofloxacin, tetracycline and ampicillin, as was observed from milk samples in Ghana (KUNADU et al., 2018), chicken carcasses in China (HU et al., 2017), and pig carcasses in Colombia (RONDÓNBARRAGÁN et al., 2015).

Although Salmonella spp. are resistant to antimicrobials occurring in different animal species around the world, especially with regard to ciprofloxacin and nalidixic acid in free-living animals, it is possible that the number of virulence and resistance genes in Salmonella spp. are limited owing to lower exposure of wildlife to antimicrobial drugs. However, anthropic action, owing to the need for greater productivity, can release wastewater into water bodies, as well as discard antimicrobial residues, thus promoting environmental contamination and, consequently, exposing animals to microorganisms with a greater possibility of resistance to these drugs.

\section{CONCLUSION}

This study is the first to report the prevalence and serovars of Salmonella spp. in freeranging wild boars in the State of São Paulo, Brazil. Results showed variability of serovars and, despite low Salmonella spp. prevalence, highlights the potential role of wild boars as carriers of Salmonella spp. transmission to wild and domestic animals and humans. Considering the widespread occurrence of free-ranging wild boars in the State of São Paulo and their potential to act as healthy carriers of a wide range of Salmonella spp. serotypes, the epidemiological role of this species in relation to salmonellosis should be further investigated.

The pattern ofmultiresistance to antimicrobials expressed by Salmonella spp. in this study highlights the risk that the indiscriminate use of antimicrobial drugs. Environmental contamination with these drugs can result in multiresistant strains of pathogens, with which wildlife, like wild boars, come into contact.

\section{ACKNOWLEDGMENTS}

The authors would like to thank the Instituto Adolfo Lutz for assistance in laboratory analysis and the hunters of São Paulo State, for contributing to the collection of samples. Also, for the laboratory support by the Fundação de Amparo à Pesquisa do Estado de São Paulo (FAPESP) and Coordenação de Aperfeiçoamento de Pessoal de Nível Superior (CAPES), Brazil Finance code 001 .

\section{BIOETHICS AND BIOSSECURITY COMMITTEE APPROVAL DECLARATION}

The study was approved by the Animal Use Ethics Commission (CEUA), from the Faculdade de Ciências Agrárias e Veterinárias (FCAV) Jaboticabal, São Paulo State University, protocol no. 014836/18, and the Chico Mendes Institute for Biodiversity Conservation (ICMBio), protocol no. 62641-2.

\section{AUTHORS' CONTRIBUTIONS}

All authors contributed equally for the conception and writing of the manuscript. All authors critically revised the manuscript and approved of the final version.

\section{DECLARATION OF CONFLICT OF INTEREST}

The authors declare no conflict of interest. The founding sponsors had no role in the design of the study; in the 
collection, analyses, or interpretation of data; in the writing of the manuscript, and in the decision to publish the results.

\section{REFERENCES}

AVAGNINA, A. et al. The microbiological conditions of carcasses from large game animals in Italy. Meat Science, v.91, n.3, p.266271, 2012. Available from: <https://www.sciencedirect.com/ science/article/pii/S0309174012000368>. Accessed: Oct. 20, 2020. doi: 10.1016/j.meatsci.2012.01.025.

BALL, T. et al. International lineages of Salmonella enterica serovars isolated from chicken farms, Wakiso District, Uganda. PloS One, v.15, n.1, p.e0220484, 2020. Available from: $<$ https://journals.plos.org/plosone/article?id=10.1371/journal. pone.0220484>. Accessed: Oct. 20, 2020. doi: 10.1371/journal. pone. 0220484 .

BARRIOS-GARCIA, M. N; BALLARI, S. A. Impact of wild boar (Sus scrofa) in its introduced and native range: a review. Biological Invasions, v.14, n.11, p.2283-2300, 2012. Available from: <https:// link.springer.com/article/10.1007/s10530-012-0229-6>. Accessed: May, 10, 2020. doi: 10.1007/s10530-012-0229-6.

BESHIRU, A. et al. Prevalence of antimicrobial resistance and virulence gene elements of Salmonella serovars from ready-to-eat (RTE) shrimps. Frontiers in Microbiology, v.10, p.1613, 2019. Available from: <https://www.frontiersin.org/articles/10.3389/ fmicb.2019.01613/full>. Accessed: Jun. 02, 2021. doi: 10.3389/ fmicb.2019.01613.

BRASIL. Portaria $n^{\circ} 126$, de 3 de novembro de 1995. Diário Oficial da República Federativa do Brasil, Brasília, DF, 6, nov. 1995, seção 1:17694-17698. Available from: <http://sistemasweb. agricultura.gov.br/sislegis/action/detalhaAto.do?method=consulta rLegislacaoFederal $>$.

BRASIL. Lei $\mathrm{n}^{\circ} 3$, de 31 de janeiro de 2013. Decreta a nocividade do javali e dispõe sobre seu manejo e controle. Diário Oficial da União, Brasília, DF, Seção 1, p.88-89, 2013.

CARLSON, J. C. et al. The role of starlings in the spread of Salmonella within concentrated animal feeding operations. Journal of Applied Ecology, v.48, n.2, p.479-486, 2011. Available from: $\quad<$ https://besjournals.onlinelibrary.wiley.com/doi/full/10.1 111/j.1365-2664.2010.01935.x>. Accessed: Mar., 11, 2020. doi: 10.1111/j.1365-2664.2010.01935.x.

CHIARI, M. et al. Salmonella serotypes in wild boars (Sus scrofa) hunted in northern Italy. Acta Veterinaria Scandinavica, v.55, n.1, p.1-4, 2013. Available from: <https://actavetscand.biomedcentral. com/articles/10.1186/1751-0147-55-42>. Accessed: Apr. 13, 2020. doi: 10.1186/1751-0147-55-42.

CLSI - Clinical and Laboratory Standards Institute. Performance standards for antimicrobial susceptibility testing [supplement M100]. Wayne: CLSI; 2017.

ECHEITA, M. A. et al. Atypical, fljB-negative Salmonella enterica subsp. enterica strain of serovar 4, 5, 12: i:- appears to be a monophasic variant of serovar Typhimurium. Journal of Clinical Microbiology, v.39, n.8, p.2981-2983, 2001. Available from: $<$ https://jcm.asm.org/content/39/8/2981.short>. Accessed: Mar. 12, 2020. doi: 10.1128/JCM.39.8.2981-2983.2001.
EFSA. The European Union summary report on trends and sources of zoonoses, zoonotic agents and food-borne outbreaks in 2016. EFSA Journal, v.15, n.12, 2017. Available from: <https://www. ncbi.nlm.nih.gov/pmc/articles/PMC7009962/>. Accessed: Mar. 12, 2020. doi: 10.2903/j.efsa.2017.5077.

EIBACH, D. et al. The emergence of reduced ciprofloxacin susceptibility in Salmonella enterica causing bloodstream infections in rural Ghana. Clinical Infectious Diseases, v.62, n.suppl_1, p.S32-S36, 2016. Available from: <https://academic. oup.com/cid/article/62/suppl_1/S32/2566523?login=true $>$. Accessed: Aug. 14, 2020. doi: 10.1093/cid/civ757.

FARIA, A. M. Escherichia coli e Salmonella sp. em suiformes nativos e exóticos assintomáticos em criações comerciais do Estado de Goiás. 2016. 66f. Tese - Programa de Pós-graduação em Ciência Animal, Universidade Federal de Goiás.

FINGER, J. A. F. F. et al. Overview of foodborne disease outbreaks in Brazil from 2000 to 2018. Foods, v.8, n.10, p.434, 2019. Available from: <https://www.mdpi.com/2304-8158/8/10/434>. Accessed: Mar. 12, 2020. doi: 10.3390/foods 8100434 .

FIROOZEH, F. et al. Antimicrobial resistance profile and presence of class I integrongs among Salmonella enterica serovars isolated from human clinical specimens in Tehran, Iran. Iranian Journal of Microbiology, v.3, n.3, p.112, 2011. Available from: $<$ https://www.ncbi. nlm.nih.gov/pmc/articles/PMC3279819/>. Accessed: Mar. 09, 2020.

FISCHER, J. et al. bla CTX-M-15-carrying Escherichia coli and Salmonella isolates from livestock and food in Germany. Journal of Antimicrobial Chemotherapy, v.69, n.11, p.2951-2958, 2014. Available from: <https://pubmed.ncbi.nlm.nih.gov/25074857/>. Accessed: Mar. 02, 2020. doi: 10.1093/jac/dku270.

FRATAMICO, P. M.; STROBAUGH, T. P. Simultaneous detection of Salmonella spp. and Escherichia coli O157:H7 by multiplex PCR. Journal of Industrial Microbiology and Biotechnology, v.21, n.3, p.92-98, 1998. Available from: $<$ https://academic.oup.com/jimb/article/21/3/92/5991354>. Accessed: Jun. 07, 2021. doi: 10.1038/sj.jim.2900520.

FREDRIKSSON-AHOMAA, M. Wild boar: a reservoir of foodborne zoonoses. Foodborne Pathogens and Disease, v.16, n.3, p.153-165, 2019. Available from: <https://www.liebertpub. com/doi/abs/10.1089/fpd.2018.2512>. Accessed: Apr. 17, 2020. doi: $10.1089 /$ fpd.2018.2512.

HILBERT, F. et al. Salmonella in the wildlife-human interface. Food Research International, v.45, n.2, p.603-608, 2012. Available from: <https://www.sciencedirect.com/science/ article/pii/S0963996911005096>. Accessed: Mar. 12, 2020. doi: 10.1016/j.foodres.2011.08.015.

HU, Y. et al. Serovar diversity and antimicrobial resistance of non-typhoidal Salmonella enterica recovered from retail chicken carcasses for sale in different regions of China. Food Control, v.81, p.46-54, 2017. Available from: <https://agris.fao.org/agrissearch/search.do?recordID $=$ US201800315688>. Accessed: Aug. 19, 2020. doi: 10.1016/j.foodcont.2017.05.031.

JIBRIL, A. H. et al. Genomic analysis of antimicrobial resistance and resistance plasmids in Salmonella serovars from poultry in Nigeria. Antibiotics, v.10, n.2, p.99, 2021. Available from: $<$ https://www.mdpi.com/2079-6382/10/2/99>. Accessed: Jun. 02, 2021. doi: 10.3390/antibiotics10020099.

KOVAC, J. et al. Temporal genomic phylogeny reconstruction indicates a geospatial transmission path of Salmonella Cerro in the 
United States and a clade-specific loss of hydrogen sulfide production. Frontiers in Microbiology, v.8, p.737, 2017. Available from: $<$ https://www.frontiersin.org/articles/10.3389/fmicb.2017.00737/ full>. Accessed: Jun. 02, 2021. doi: 10.3389/fmicb.2017.00737.

KUNADU, A. P. H. et al. Microbiological quality and antimicrobial resistance characterization of Salmonella spp. in fresh milk value chains in Ghana. International Journal of Food Microbiology, v.277, p.41-49, 2018. Available from: $<$ https://www.sciencedirect. com/science/article/pii/S0168160518301764>. Accessed: Oct. 03, 2020. doi: 10.1016/j.ijfoodmicro.2018.04.025.

LITERAK, I. et al. Antimicrobial-resistant faecal Escherichia coli in wild mammals in central Europe: multiresistant Escherichia coli producing extended- pectrum beta-lactamases in wild boars. Journal of Applied Microbiology, v.108, n.5, p.1702-1711, 2010. Available from: <https://sfamjournals.onlinelibrary.wiley.com/ doi/full/10.1111/j.1365-2672.2009.04572.x>. Accessed: Aug. 11, 2020. doi: $10.1111 / j .1365-2672.2009 .04572 . x$.

LÚCIO, C. J. et al. Occurrence of Salmonella spp. in broiler chicken feces in the central region of the state of Minas Gerais, Brazil. Journal of Tropical Pathology, v.48, n.2, p.79-86, 2019. Available from: $<$ https://www.revistas.ufg.br/iptsp/article/view/59106>. Accessed: Jun. 07, 2021. doi: 10.5216/rpt.v48i2.59106.

MEIER, R.; RYSER-DEGIORGIS, M. Wild boar and infectious diseases: evaluation of the current risk to human and domestic animal health in Switzerland: A review. Schweiz Arch Tierheilkd, v.160, n.78, p.443-460, 2018. Available from: <https://pubmed.ncbi.nlm.nih. gov/29989552/>. Accessed: Aug. 14, 2020. doi: 10.17236/sat00168.

MIRCETA, J. et al. Assessment of microbial carcass contamination of hunted wild boars. European Journal of Wildlife Research, v.63, n.2, p.37, 2017. Available from: <https://link.springer.com/ content/pdf/10.1007/s10344-017-1096-3.pdf $>$. Accessed: Oct. 24, 2020. doi: $10.1007 / \mathrm{s} 10344-017-1096-3$

MOLINA-LÓPEZ, R. A. et al. Multidrug-resistant Salmonella enterica serovar Typhimurium monophasic variant 4,12 : i:- isolated from asymptomatic wildlife in a catalonian wildlife rehabilitation center, Spain. Journal of Wildlife Diseases, v.51, n.3, p.759-763, 2015. Available from: <https://meridian.allenpress.com/jwd/article/51/3/759/123497>. Accessed: Jan. 25, 2020. doi: 10.7589/2015-01-019.

MOLINO, M. G. et al. Prevalence of Salmonella spp. in tonsils, mandibular lymph nodes and faeces of wild boar from Spain and genetic relationship between isolates. Transboundary and Emerging Diseases, v.66, n.3, p.1218-1226, 2019. Available from: $<$ https://onlinelibrary.wiley.com/doi/abs/10.1111/tbed.13140>. Accessed: Feb. 22, 2020. doi: 10.1111/tbed.13140.

NAVARRO-GONZALEZ, N. et al. Effect of cattle on Salmonella carriage, diversity and antimicrobial resistance in free-ranging wild boar (Sus scrofa) in northeastern Spain. PloS One, v.7, n.12, p.e51614, 2012. Available from: <https://journals.plos.org/ plosone/article?id=10.1371/journal.pone.0051614>. $\quad$ Accessed: Sept. 15, 2020. doi: 10.1371/journal.pone.0051614.

NOUICHI, S. et al. Prevalence and antimicrobial resistance of Salmonella isolated from bovine and ovine samples in slaughterhouses of Algiers, Algeria. Journal of the Hellenic Veterinary Medical Society, v.69, n.1, p.863-872, 2018. Available from: <https://ejournals.epublishing.ekt.gr/index.php/jhvms/article/ view/16441 >. Accessed: May, 30, 2021. doi: 10.12681/jhvms.16441.
PAULSEN, P. et al. Salmonella in meat from hunted game: A Central European perspective. Food Research International, v.45, n.2, p.609-616, 2012. Available from: <https://www.sciencedirect. com/science/article/pii/S0963996911004376>. Accessed: Oct. 26, 2020. doi: 10.1016/j.foodres.2011.06.055.

PEDROSA, F. et al. Current distribution of invasive feral pigs in Brazil: economicimpacts and ecological uncertainty. Natureza \& Conservação, v.13, p.84-87, 2015. Available from: <https://www.sciencedirect.com/ science/article/pii/S1679007315000092?via\%3Dihub>. Accessed: Mar. 17, 2020. doi: 10.1016/j.ncon.2015.04.005.

PIRES, A. F. A. et al. Longitudinal study of Salmonella shedding in naturally infected finishing pigs. Epidemiology \& Infection, v.141, n.9, p.1928-1936, 2013. Available from: <https://pubmed. ncbi.nlm.nih.gov/23148875/>. Accessed: Aug. 02, 2020. doi: $10.1017 /$ S0950268812002464.

QUESADA, A. et al. Polymorphism of genes encoding PmrAB in colistin-resistant strains of Escherichia coli and Salmonella enterica isolated from poultry and swine. Journal of Antimicrobial Chemotherapy, v.70, n.1, p.71-74, 2015. Available from: $<$ https:// academic.oup.com/jac/article/70/1/71/2911064? login=true $>$. Accessed: Mar. 08, 2020. doi: 10.1093/jac/dku320.

RONDÓN-BARRAGÁN, I. S. et al. Characterization of Salmonella species from pork meat in Tolima, Colombia. Revista Colombiana de Ciencias Pecuarias, v.28, n.1, p.74-82, 2015. Available from: <https://revistas.udea.edu.co/index.php/rccp/ article/view/324913>. Accessed: Aug. 18, 2020.

SANNÖ, A. et al. Distribution of enteropathogenic Yersinia spp. and Salmonella spp. in the Swedish wild boar population, and assessment of risk factors that may affect their prevalence. Acta Veterinaria Scandinavica, v.60, n.1, p.1-9, 2018. Available from: $<$ https://link.springer.com/article/10.1186/s13028-018-0395-3>. Accessed: Oct. 24, 2020. doi: 10.1186/s13028-018-0395-3.

SCHIERACK, P. et al. Porcine E. coli: virulence-associated genes, resistance genes and adhesion and probiotic activity tested by a new screening method. PloS One, v.8, n.4, p.e59242, 2013. Available from: <https://journals.plos. org/plosone/article?id=10.1371/journal.pone.0059242>. Accessed: Jun. 11, 2020. doi: 10.1371/journal.pone.0059242.

SCHWARZ, S. et al. Assessing the antimicrobial susceptibility of bacteria obtained from animals. Journal of Antimicrobial Chemotherapy, v.65, n.4, p.601-604, 2010. Available from: $<$ https://academic.oup.com/jac/article/65/4/601/831984?login=tr ue>. Accessed: Mar. 08, 2020. doi: 10.1093/jac/dkq037.

THAKUR, S. et al. Detection of Clostridium difficile and Salmonella in feral swine population in North Carolina. Journal of Wildlife Diseases, v.47, n.3, p.774-776, 2011. Available from: $<$ https://europepmc.org/article/med/21719851>. Accessed: Feb. 12, 2020. doi: 10.7589/0090-3558-47.3.774.

VIEIRA-PINTO, M. et al. Salmonella sp. in game (Sus scrofa and Oryctolagus cuniculus). Foodborne Pathogens and Disease, v.8, n.6, p.739-740, 2011. Available from: <https://www.liebertpub. com/doi/abs/10.1089/fpd.2010.0742>. Accessed: Feb. 13, 2020. doi: $10.1089 /$ fpd.2010.0742.

WACHECK, S. et al. Wild boars as an important reservoir for foodborne pathogens. Foodborne Pathogens and Disease, v.7, n.3, p.307-312, 2010. Available from: <https://www.liebertpub. com/doi/abs/10.1089/fpd.2009.0367>. Accessed: Aug. 18, 2020. doi: 10.1089/fpd.2009.0367.

Ciência Rural, v.52, n.8, 2022. 